\title{
Evidence of Member Hotel Programs Boosting Loyalty
}

\author{
MiRan Kim \\ Michigan State University, \\ Michigan, USA
}

\author{
Christine A. Vogt \\ Arizona State University, \\ Arizona, USA
}

\author{
Bonnie J. Knutson \\ Michigan State University, \\ Michigan, USA
}

\begin{abstract}
This study extends previous research on tourists' loyalty by measuring the duel dimensions of loyalty toward a destination resort - attitudinal and behavioral. A satisfaction-loyalty model was tested using an online survey and the resort's reservation database. Customers' satisfaction with the value for their money and their overall satisfaction ratings were found to be significant predictors of attitudinal loyalty. Customers' satisfaction with room cleanliness and comfort was found to be a significant predictor of behavioral loyalty. Members of the hotel's loyalty program were found to have stronger ties between attitudinal loyalty and behavioral loyalty. Implications for management and future research are presented.
\end{abstract}

Keywords: consumer behavior, satisfaction, attitudinal loyalty, behavioral loyalty, hotel membership program

\section{Introduction}

Both marketing scholars and practitioners have learned that measuring only attitudinal loyalty and at a single point in time following a purchase is not sufficient for predicting future purchase behaviors, as customers' intentions can change over time (Bodet, 2008; Budeanu, 2007; Chandon, Morwitz, \& Reinartz, 2005; Li \& Petrick, 2008a; 2010; McKercher \& Tse, 2012; Oppermann, 2000; Petrick, 2005). Most loyalty studies in the hospitality and tourism field tend only to measure attitudinal factors, such as intention to repurchase or commitment to specific brands, and do not include actual behavior measures, even though, over time, attitudinal loyalty has been viewed as an acceptable or available predictor of future behavioral loyalty (Kwortnik \& Han, 2011; McKercher \& Tse, 2012; Oppermann, 1999; Shoemaker \& Bowen, 2003).

Customer or transactional databases can allow for modeling of customers' future transactions, but are often difficult to obtain because of proprietary interests. Moreover, these databases may not ever be linked to survey data that would include satisfaction ratings with specific purchases, intentions to return, or recommendations to others.

A loyalty or membership program aims to build customer loyalty to a brand by providing rewards and added benefits to those customers willing to sign up and sometimes pay a nominal fee (Bolton, Kannan, \& Bramlett, 2000; Yi \& Jeon, 2003) and databases from loyalty programs can provide a wealth of data for researchers to improve modeling of consumer behavior.

MiRan Kim, Ph.D., assistant professor, School of Hospitality Business, Michigan State University. Email: kimmi8@msu.edu.

Christine A. Vogt, Ph.D., professor, director, Center for Sustainable Tourism, School of Community Resources and Development, College of Public Service and Community Solutions, Arizona State University.

Bonnie J. Knutson, Ph.D., professor, School of Hospitality Business, Michigan State University. 
Therefore, a need exists for research that captures customers' intentions and tracks actual purchase behaviors. In order to fill this gap in consumer behavior research, this study is designed to examine customer satisfaction, attitudinal loyalty, and behavioral loyalty relationships and test those relationships for two distinct segments: hotel guests with loyalty membership and guests without. The theoretical contribution of this research is to gain a better understanding of the predictive validity between attitudinal loyalty and behavioral loyalty in the context of hospitality.

\section{Literature Review}

\section{Customer Satisfaction}

Hospitality managers, employees, and destination marketers are always striving to develop products and services that will increase customer satisfaction. This is a challenging task given increasing market competition, more sophisticated and experienced consumers, and the proliferation of information available via the proliferation of new media channels and social media.

Customer satisfaction is defined as a cognitive state resulting from cognitive and emotional processes of customers' comparisons between their expectations of performance and actual performance and experience (Oliver, 1980). Recently, understanding customers' emotional needs becomes an important aspect of understanding their satisfaction (Bigné, Küster, \& Torán, 2003). Expectations are simply beliefs that a product/service will produce certain outcomes. They are formed from past experiences with the brand, comments from friends and family, as well as adverts and other promotional materials put out by the company. For a consumer, a brand experience can have one of three outcomes; it can exceed expectations, meet expectations, or fall below expectations. Positive disconfirmation occurs when performance perceptions of the customer exceed his or her expectations; this, then, leads to satisfaction (Abubakar \& Mavondo, 2014; Oliver, 1980).

Many studies, which have surveyed customers closely following a hotel stay, have shown that customer satisfaction is a strong indicator of a guest's intention to revisit and recommend the destination or property to others (Back \& Parks, 2003; Bramwell, 1998; Fornell, Johnson, Anderson, Cha, \& Bryant, 1996; Han \& Back, 2007; Kozak, 2001; Kozak \& Rimmington, 2000; Li \& Petrick, 2008b; Yi \& La, 2004). Back and Parks (2003) and Fornell et al. (1996) further found that customer satisfaction increased brand loyalty in terms of how likely they are to repurchase the product or service and how much they are willing to pay at that time. Getty and Thompson (1995) also found that customers' intentions to recommend a hotel to others were a function of their own perception of satisfaction and service quality during their visits.

Customer satisfaction is operationalized at an overall and attributes-specific level (Oliver, 1993). Overall satisfaction is based on the combined experience or a summary evaluation of the entire product or service experience, and attribute satisfaction is based on the customer's subjective satisfaction judgment resulting from observations of attribute performance (Spreng, MacKenzie, \& Olshavsky, 1996). There are several hotel attributes consistently reported in the satisfaction literature, i.e., friendliness of staff, facilities and amenities, location, service quality, quality of food, room cleanliness, room comfort, safety/security, and value for the money spent (Dubé \& Renaghan, 2000; Knutson, 1988; Tsai, Yeung, \& Yim, 2011).

\section{Customer Loyalty}

Loyalty, specifically attitudinal loyalty, has become a way to capture and understand the customer's inclination toward a brand. Researchers view attitudinal loyalty as a function of psychological processes associated with purchase behaviors (Dick \& Basu, 1994; Jacoby \& Chestnut, 1978). In tourism, attitudinal 
loyalty has been measured by the level of customer's intentions to revisit a destination or repurchase at a business, and in their willingness to recommend a destination or specific business to others (Li \& Petrick, 2008a; 2010; Oppermann, 2000; Yi \& La, 2004; Yoon \& Uysal, 2005). Hospitality experiences are particularly believed to include affective attributes because of the experience nature of vacations compared to "good" products (Back, 2005; Kim, Lee, \& Mattila, 2014; Schall, 2003).

Behavioral loyalty is defined as the consumer's actual repurchase behavior that is measured and directly impacts brand sales and profits (Hammond, East, \& Ehrenberg, 1996; Russell-Bennett, McColl-Kennedy, \& Coote, 2007). Considering only the behavioral aspects of loyalty in conjunction with attitudinal loyalty may mask those customers who are truly loyal and those who are deal-oriented and lack psychological attachment (Bandyopadhyay \& Martell, 2007; Day, 1969; Pritchard, Howard, \& Havitz, 1992). Thus, behavioral measures alone are insufficient in explaining consumer behavior, particularly loyal customers.

While many studies have investigated the relationship between customer satisfaction and attitudinal loyalty, only a few empirical studies have tested the relationship between customer satisfaction and behavioral loyalty in the hospitality setting (Back \& Parks, 2003; Bodet, 2008). Back and Parks (2003) found a significant relationship between customer satisfaction and behavioral loyalty with mediation from attitudinal loyalty, and Bodet (2008) found that neither customer satisfaction nor attitudinal loyalty directly predicted behavioral loyalty. In their study of two different service industries: health care and car repair, Mittal and Lassar (1998) reported that customer satisfaction does not guarantee loyalty even among the highly satisfied customers as satisfied customers showed willingness to switch service providers. Although customer satisfaction contributes to behavioral loyalty, it is not sufficient to directly predict behavioral loyalty (Bodet, 2008; Mittal \& Lassar, 1998).

If studies show that satisfaction has no direct influence on behavioral loyalty, then an important question arises. What, if anything, is the relationship between satisfaction and behavioral loyalty? According to an attitude-based loyalty framework, prospective customers would first develop positive affective attachment and beliefs about a provider, then form an attitude, and finally form intentions to purchase from that preferred provider. The theory of reasoned action (Ajzen \& Fishbein, 1980) explains that a patronizing behavior toward a provider is the result of attitude development, as attitude influences actual behavior by positively reinforcing behavioral intention (Bentler \& Speckart, 1979; Dick \& Basu, 1994; Oliver, 1999). Loyalty researchers frequently use attitude to explain behavior, thus conceptualizing loyalty from a causal perspective (Baldinger \& Rubinson, 1996; Dick \& Basu, 1994). Oliver (1999) found positive attitudes toward a certain purchase experience changed attitudes toward the product or brand, such as an increased level of positive belief and positive effect, and enhanced repurchase intentions (Oliver, 1999). When the relative strength of an attitude toward the brand is stronger than other brands in the same category, attitudinal loyalty toward that brand increases as the result of attitude development (Dick \& Basu, 1994; Evanschitzky, Iyer, Plassmann, Niessing, \& Meffert, 2006; Morais, Dorsch, \& Backman, 2004; Oliver, 1999).

Attitudinal loyalty emphasizes the importance of understanding customers' intention to purchase, while behavioral loyalty emphasizes customers' life-time value to a business. Therefore, a loyalty with a strong operational strategic plan can assist in developing more cost-effective marketing strategies to increase this life-time value (O’Malley, 1998). The attitude-behavior relationship has been supported by empirical studies (Bagozzi, Baumgartner, \& Yi, 1989; Fishbein \& Ajzen, 1975), as well as not supported (Back \& Parks, 2003). Therefore, this study was conducted to understand better the relationship among satisfaction, attitudinal loyalty, and behavioral loyalty, within the hospitality context, in general, and the lodging sector, in particular. 
A loyalty or membership program can become a more reliable tool for hospitality business to learn more about their customers' behaviors and future intentions to purchase. Hospitality businesses will continue to emphasize customer satisfaction, and a loyalty program is prevalent worldwide in the hospitality industry and may be the more dominant and direct way to a lifetime customer (Meyer-Waarden, 2008; B. Sharp \& A. Sharp, 1997; Yi \& Jeon, 2003). Customer loyalty programs aim to accelerate the loyalty life cycle and create switching costs (a cost to leaving or a cost to joining a competitor's program). Loyal customers have been shown to buy more, pay higher prices by utilizing the rewards/added benefits, and bring in new customers from recommendations (Carlsson \& Löfgren, 2006; O’Brien \& Jones, 1995; B. Sharp \& A. Sharp, 1997; Thaler, 1985; Wright \& Sparks, 1999; Yi \& Jeon, 2003).

Some studies have examined the impact of customer loyalty program on customer loyalty (Bridson, Evans, \& Hickman, 2008; Jang \& Mattila, 2005) and showed that loyalty program members and non-members have different purchasing behaviors and loyalty program members identify more strongly with a company (Meyer-Waarden, 2008). However, few empirical studies have examined the relationships among satisfaction, loyalty, and future purchase behaviors nor have they evaluated the contribution of a loyalty or member program to those relationships. Therefore, this study examines the role of loyalty membership in the relationships between satisfaction and loyalty.

\section{Methodology}

\section{Sample Frame}

The sample for this study was drawn from the database of a large Midwestern resort that has been in operation for more than three decades. It is independently owned and operated and benefits from an extensive guests database that is populated with data from a well-established loyalty program. The loyalty program does require a nominal annual membership fee and includes benefits such as complimentary overnight stays, discounts at area restaurants that are operated by the same owners along with retail venues within the resort. The resort is not affiliated with any national or international hotel brands.

Based on the literature review and the research objectives, and with the cooperation of the resort's management, a two-phase (Time 1 and Time 2) study was designed. Time 1 data measured respondents' satisfaction with their most recent overnight experience at the resort, as well as their attitudinal loyalty toward that property. An online questionnaire was used to capture these data.

Over nine weeks, the researchers worked with a database manager to obtain recent customer records to create sampling frames for each week. Qualtrics was used to host the survey instrument and sent to each week's list of customers, excluding those who did not have email addresses. A customer may have received a survey one day after their stay or up to seven days after. Reminder emails were sent to each of the nine waves for up to four weeks after the initial email was sent. An incentive offer was also included in the email. Respondents who completed the survey received discount coupons from the resort and were given a chance to enter into a drawing for one grand prize for a stay at the resort.

In this study, 1,573 hotel guests (46\% response rate) completed online surveys to measure their satisfaction and attitudinal loyalty at Time 1 . The majority of the respondents resided in Michigan $(n=1,091)$ with the remaining from other states (e.g., Ohio, Canada) $(n=482)$. Only the respondents from Michigan $(n=1,091)$ were analyzed for this study to reduce the influence of travel times and costs and more accurately predict behaviors. To test the role of loyalty membership, respondents were segmented into guests with 
membership ( $n=584)$ and those without membership $(n=507)$. A year later, the resort's data manager provided researchers with data that identified whether the respondents again booked/stayed at the resort within the year following their initial stay. These data were treated as the behavioral loyalty measure and analyzed as Time 2 data. With these two points in time, it was possible to investigate the relationship among satisfaction, attitudinal loyalty, and actual behavioral loyalty.

\section{Questionnaire Development}

The survey items used in this research were derived from the literature and framed for the respondent as being related to their most recent visit to the property. For hotel attribute-level satisfaction, six items were selected (Dubé \& Renaghan, 2000; Knutson, 1988; Tsai et al., 2011); for example, "friendliness of staff”, "hotel facilities and amenities", "hotel location", "quality of food", "room cleanliness and comfort", and "value for money". Responses were given on a 7-point Likert scale from " 1 = very unsatisfied” to "7 = very satisfied".

Overall customer satisfaction was measured with one item, again using a 7-point Likert scale from "1 = strongly disagree" to "7 = strongly agree" with the following statement: "Overall, this hotel was satisfying" (Finn, 2005; Spreng et al., 1996). To measure attitudinal loyalty, two items were measured based on a 7-point Likert scale from " 1 = extremely unlikely" to "7 = quite likely" with the following statements: "I will return to this hotel in the next 12 months" and "I will recommend this hotel to others" (Li \& Petrick, 2008b; McMullan \& Gilmore, 2003; Oppermann, 1999; Yi \& La, 2004; Yoon \& Uysal, 2005). These satisfaction and attitudinal loyalty items were measured at Time 1 , which was treated as within seven days of checking out of the hotel property.

Behavioral loyalty was the frequency of actual follow-up stays obtained from the hotel's database. This behavior measure was treated as Time 2 and represents the passage of one year from the last wave of customer stays that occurred close to Time 1 . Actual repeat visit data were used to test the predictive validity between attitudinal loyalty and behavioral loyalty measures (McKercher \& Tse, 2012).

\section{Data Analysis}

Survey data were analyzed using SPSS 22.0 software for descriptive statistics. To examine any relationships among satisfaction, attitudinal and behavioral loyalty, independent-samples $t$-test and multiple regression analysis were performed. Chi-square test was also conducted to examine the distribution of attribute satisfaction and overall satisfaction levels.

\section{Findings}

\section{Respondent Profile}

The participant demographics from the online survey showed that the majority of the respondents were female (71\%) and of Caucasian descent (81\%). The average age was 44 years old; about two-thirds of the respondents had an annual household income over $\$ 50,000$, and the average size household was three. Within the 12 months following from their initial stay, nearly $47 \%$ of the survey respondents returned as overnight guests at this hotel according to data obtained from the hotel's actual customer records. Of that number, $61 \%$ of them revisited this hotel one time and $39 \%$ of the guests revisited this hotel two or more times. 
Table 1

Socio-demographic Characteristics of Survey Respondents Between Loyalty Program Members and Loyalty Program Non-members

\begin{tabular}{|c|c|c|c|c|c|}
\hline \multirow[t]{2}{*}{ Characteristic $^{\mathrm{a}}$} & \multirow[t]{2}{*}{ Category } & \multicolumn{2}{|c|}{$\begin{array}{l}\text { Loyalty program members } \\
\qquad(n=584)\end{array}$} & \multicolumn{2}{|c|}{$\begin{array}{l}\text { Loyalty program non-members } \\
\qquad(n=507)\end{array}$} \\
\hline & & Frequency & $\%$ & Frequency & $\%$ \\
\hline \multirow{3}{*}{ Gender } & Female & 344 & 69.4 & 298 & 74.1 \\
\hline & Male & 152 & 30.6 & 104 & 25.9 \\
\hline & Total & 496 & 100 & 402 & 100 \\
\hline \multirow{8}{*}{ Race } & Caucasian & 403 & 81.6 & 324 & 81.4 \\
\hline & American Indian & 16 & 3.2 & 11 & 2.8 \\
\hline & Asian or Pacific & & & & \\
\hline & Islander & 4 & 0.8 & 1 & 0.3 \\
\hline & Hispanic/Latino/Latina & 3 & 0.6 & 5 & 1.3 \\
\hline & African American/Black & 12 & 2.4 & 14 & 3.5 \\
\hline & Other & 56 & 11.4 & 43 & 10.7 \\
\hline & Total & 494 & 100 & 398 & 100 \\
\hline \multirow{7}{*}{ Employment status } & Employed full-time & 279 & 57.1 & 256 & 63.7 \\
\hline & Employed part-time & 57 & 11.7 & 46 & 11.4 \\
\hline & Retired & 59 & 11.8 & 35 & 8.7 \\
\hline & Self-employed & 40 & 8.2 & 31 & 7.7 \\
\hline & Unemployed & 23 & 4.7 & 22 & 5.5 \\
\hline & Other & 31 & 6.5 & 12 & 3.0 \\
\hline & Total & 489 & 100 & 402 & 100 \\
\hline \multirow{10}{*}{ Income } & Less than $\$ 25,000$ & 22 & 4.5 & 17 & 4.4 \\
\hline & $\$ 25,000-\$ 34,999$ & 30 & 6.2 & 28 & 7.2 \\
\hline & $\$ 35,000-\$ 49,999$ & 62 & 12.4 & 37 & 9.5 \\
\hline & $\$ 50,000-\$ 74,999$ & 118 & 23.6 & 92 & 23.6 \\
\hline & $\$ 75,000-\$ 99,999$ & 86 & 17.2 & 64 & 16.4 \\
\hline & $\$ 100,000-\$ 149,999$ & 74 & 14.8 & 71 & 18.2 \\
\hline & $\$ 150,000-\$ 199,999$ & 12 & 2.4 & 18 & 4.6 \\
\hline & $\$ 200,000$ or more & 2 & 0.4 & 16 & 4.1 \\
\hline & I prefer not to respond & 78 & 18.5 & 47 & 12.0 \\
\hline & Total & 484 & 100 & 390 & 100 \\
\hline Age & Mean & & 44 years & & 45 years \\
\hline
\end{tabular}

Note. ${ }^{\text {a }}$. All variables measured at Time 1.

As shown in Table 1, the demographic characteristics (i.e., gender, race, age, employment status, and income) were closely compared to determine whether there were significant differences between loyalty members and non-members. The majority of the participants were female (members: 69.4\%; non-members: 74.1\%) and the average ages were 44 years old (members) and 45 years old (non-members). The majority of the participants (members: 81.6\%; non-members: 81.4\%) were of Caucasian descent. More than half of the respondents had an annual household income over \$50,000 (members: 58.4\%; non-members: 66.9\%). The majority of the respondents were full-time employees (members: 57.1\%; non-members: 63.7\%).

As shown in Table 2, a chi-square test was performed to examine a frequency distribution of satisfaction levels (i.e., very unsatisfied, neutral, very satisfied) of six hotel attributes and overall satisfaction. All of the variables were significant (satisfaction with hotel location: $X^{2}(2, n=1,067)=1,839.14, p<0.001$; friendliness 
of staff: $X^{2}(2, n=1,084)=1,626.95, p<0.001$; hotel facilities and amenities: $X^{2}(2, n=1,058)=1,476.21$, $p<0.001$; room cleanliness and comfort: $X^{2}(2, n=1,065)=1,558.55, p<0.001$; quality of food: $X^{2}(2, n=989)=1,043.49, p<0.001$; value for money: $X^{2}(2, n=1,072)=573.50, p<0.001$; overall satisfaction: $\left.X^{2}(2, n=1,091)=1,193.16, p<0.001\right)$, which means that the distribution of satisfaction levels of each hotel attribute and overall satisfaction was not similarly distributed in the populations. Each variable showed that the frequency of "very satisfied guests" group was much higher than that of "very unsatisfied" and "neutral” groups.

Another chi-square test was performed to examine the relationship between loyalty program and the distribution of satisfaction levels. Significant relationships were found between them with hotel satisfaction with value for money $\left(X^{2}(2, n=584)=13.76, p<0.01\right)$ and overall satisfaction $\left(X^{2}(2, n=584)=6.89\right.$, $p<0.05)$.

Table 2

Distribution of Satisfaction Levels and Results of Chi-square Tests

\begin{tabular}{|c|c|c|c|c|c|c|c|c|c|c|c|}
\hline \multirow[t]{2}{*}{ Satisfaction with } & \multicolumn{3}{|c|}{$\begin{array}{c}\text { Total sample } \\
(n=1,091)\end{array}$} & \multirow{2}{*}{$\begin{array}{l}\text { Chi-square } \\
\text { test }^{\text {a }} \\
p \text {-value }\end{array}$} & \multicolumn{3}{|c|}{$\begin{array}{c}\text { Loyalty program } \\
\text { members } \\
(n=584) \\
\end{array}$} & \multirow{2}{*}{$\begin{array}{l}\begin{array}{l}\text { Chi-square } \\
\text { test }^{\mathrm{b}}\end{array} \\
p \text {-value }\end{array}$} & \multicolumn{3}{|c|}{$\begin{array}{l}\text { Loyalty program } \\
\text { non-members } \\
(n=507)\end{array}$} \\
\hline & $\%^{\mathrm{c}}$ & $\%^{\mathrm{d}}$ & $\%^{\mathrm{e}}$ & & $\%^{\mathrm{c}}$ & $\%^{\mathrm{d}}$ & $\%^{\mathrm{e}}$ & & $\%^{\mathrm{c}}$ & $\%^{\mathrm{d}}$ & $\%^{\mathrm{e}}$ \\
\hline Hotel location & 1.9 & 2.9 & 95.2 & 0.000 & 1.8 & 2.7 & 95.5 & 0.748 & 3.2 & 2.2 & 94.6 \\
\hline $\begin{array}{l}\text { Friendliness of } \\
\text { staff }\end{array}$ & 2.8 & 6.2 & 91.0 & 0.000 & 2.8 & 5.4 & 91.8 & 0.631 & 7.4 & 5.9 & 86.7 \\
\hline $\begin{array}{l}\text { Hotel facilities and } \\
\text { amenities }\end{array}$ & 3.0 & 8.0 & 89.0 & 0.000 & 2.9 & 8.4 & 88.7 & 0.650 & 4.0 & 7.6 & 88.4 \\
\hline $\begin{array}{l}\text { Room cleanliness } \\
\text { and comfort }\end{array}$ & 3.2 & 6.5 & 90.3 & 0.000 & 4.1 & 6.6 & 89.3 & 0.393 & 3.0 & 7.5 & 89.5 \\
\hline Quality of food & 3.0 & 15.8 & 81.2 & 0.000 & 2.8 & 14.6 & 82.6 & 0.690 & 3.7 & 15.5 & 80.8 \\
\hline Value for money & 6.2 & 28.5 & 65.3 & 0.000 & 5.7 & 26.0 & 68.3 & 0.001 & 7.5 & 32.3 & 60.2 \\
\hline Overall satisfaction & 2.2 & 12.4 & 85.4 & 0.000 & 2.2 & 11.0 & 86.8 & 0.032 & 3.4 & 14.7 & 81.9 \\
\hline
\end{tabular}

Notes. ${ }^{\text {a }}$. Chi-square test of the distribution among very unsatisfied, neutral, and very satisfied. ${ }^{b}$. Chi-square test of the relationship between loyalty program and satisfaction distribution levels. ${ }^{c}$. Percentage of respondents who were very unsatisfied.

d. Percentage of respondents who were neutral. ${ }^{e}$. Percentage of respondents who were very satisfied.

As shown in Table 3, an independent-samples $t$-test was conducted to compare satisfaction between loyalty members and non-members. There were significant differences in the scores of "satisfaction with value for money" for loyalty members $(\mathrm{M}=5.80, \mathrm{SD}=0.063)$ and non-loyalty members $(\mathrm{M}=5.46, \mathrm{SD}=0.073)$ conditions; $t(1,089)=3.55, p<0.001$ and "overall satisfaction" for loyalty members $(\mathrm{M}=6.21, \mathrm{SD}=0.044)$ and non-loyalty members $(\mathrm{M}=5.96, \mathrm{SD}=0.054)$ conditions; $t(1,089)=3.70, p<0.001$. Satisfaction ratings of the six attributes were highly rated with friendliness of staff (Mean of total sample 6.42 from 1 = very unsatisfied to 7 = very satisfied, members: 6.46, non-members: 6.40), hotel facilities and amenities (pool, game room, free nightly entertainment) (total sample: 6.37, members: 6.46, non-members: 6.38), hotel location (total sample: 6.63, members: 6.68, non-members: 6.60), quality of food (total sample: 6.14, members: 6.32, non-members: 6.28), room cleanliness and comfort (total sample: 6.27, members: 6.22, non-members: 5.98), and value for money (total sample: 5.64, members: 5.80, non-members: 5.46). Overall customer satisfaction was also highly rated (total sample: 6.09, members: 6.21, non-members: 5.96). 
Table 3

Means of Customer Satisfaction - Hotel Attributes and Overall Measures

\begin{tabular}{|c|c|c|c|c|c|}
\hline \multirow[t]{2}{*}{ Satisfaction with } & \multirow{2}{*}{$\begin{array}{l}\text { Total sample } \\
(n=1,091) \\
\text { Mean }^{\mathrm{a}}\end{array}$} & \multirow{2}{*}{$\begin{array}{l}\text { Loyalty program } \\
\text { members } \\
(n=584) \\
\text { Mean }^{\mathrm{a}}\end{array}$} & \multirow{2}{*}{$\begin{array}{l}\text { Loyalty program } \\
\text { non-members } \\
(n=507) \\
\text { Mean }^{\mathrm{a}}\end{array}$} & \multicolumn{2}{|c|}{$\begin{array}{c}\text { Independent samples } \\
t \text {-test }\end{array}$} \\
\hline & & & & $t$-value & $p$-value \\
\hline Hotel location & 6.63 & 6.68 & 6.60 & 1.26 & Non-sig. \\
\hline Friendliness of staff & 6.42 & 6.46 & 6.40 & 0.90 & Non-sig. \\
\hline Hotel facilities and amenities & 6.37 & 6.46 & 6.38 & 1.06 & Non-sig. \\
\hline Room cleanliness and comfort & 6.27 & 6.22 & 5.98 & 0.12 & Non-sig. \\
\hline Quality of food & 6.14 & 6.32 & 6.28 & 0.46 & Non-sig. \\
\hline Value for money & 5.64 & 5.80 & 5.46 & 3.55 & 0.000 \\
\hline Overall satisfaction & 6.09 & 6.21 & 5.96 & 3.70 & 0.000 \\
\hline
\end{tabular}

Note. ${ }^{\text {a }}$. Scale where 1: Very unsatisfied to 7: Very satisfied.

Multiple regression analysis was conducted to confirm the relationships among variables. As shown in Table 4 and Figure 1, multiple regression analysis was conducted to examine the relationships among customer satisfaction (overall, attributes), attitudinal loyalty, and behavioral loyalty. The variables "friendliness of staff", "hotel facilities and amenities”, "hotel location”, “quality of food”, "room cleanliness and comfort”, "value for money”, and "overall customer satisfaction" were entered simultaneously into the analysis. Satisfaction ratings on two hotel attributes variables were found to be significantly related with attitudinal loyalty: "satisfaction with value for money" ( $\beta=0.23, p<0.001)$ and "overall satisfaction" $(\beta=0.52, p<0.001)$. The model accounted for $37 \%$ of the variance in attitudinal loyalty, $F(9,897)=61.64, p<0.001$.

Table 4

Multiple Regression Analysis of Customer Satisfaction, Attitudinal Loyalty, and Behavioral Loyalty

\begin{tabular}{llllll}
\hline \multirow{2}{*}{ Variable } & \multicolumn{3}{c}{ Attitudinal loyalty } & & \multicolumn{2}{c}{ Behavioral loyalty } \\
\cline { 2 - 3 } \cline { 5 - 6 } & $\beta$ & & $p$-value & & $p$-value \\
\hline Satisfaction with room cleanliness and comfort & -0.06 & Non-sig. & & 0.10 & $<0.05$ \\
Satisfaction with value for money & 0.23 & $<0.001$ & & -0.01 & Non-sig. \\
Overall customer satisfaction & 0.52 & $<0.001$ & & 0.002 & Non-sig. \\
Attitudinal loyalty & -- & -- & -0.003 & Non-sig. \\
$R^{2}$ & & $37 \%$ & & $1 \%$ \\
\hline
\end{tabular}

Behavioral loyalty was regressed on hotel satisfaction and attitudinal loyalty (see Table 4); "satisfaction with room cleanliness and comfort” $(\beta=0.10, p<0.05)$ was found to be positively related to behavioral loyalty. The eight predictor model accounted for $1 \%$ of the variance in behavioral loyalty, $F(10,896)=1.15, p>0.05$. Based on the results, no significant relationship between attitudinal loyalty and behavioral loyalty was found.

Next, multiple regression analyses were repeated but using a segmented dataset: guests with loyalty membership versus guests without loyalty membership. As shown in Table 5, "satisfaction with value for money" ( $\beta=0.24, p<0.001)$ and "overall satisfaction" ( $\beta=0.47, p<0.001)$ were found to be positively related to attitudinal loyalty. For those customers who did not belong to a membership program, "satisfaction with hotel location" ( $\beta=0.14, p<0.05)$ and "overall satisfaction" $(\beta=0.57, p<0.001)$ were positively related to attitudinal loyalty. For behavioral loyalty, guest members were positively influenced to return by being satisfied with the value they perceived to have received on their previous stay $(\beta=0.14, p<0.05)$ and attitudinal loyalty $(\beta=0.09, p<0.05)$, whereas non-members were influenced by the satisfaction with room 
cleanliness and comfort during their previous stay $(\beta=0.17, p<0.05)$ and not attitudinal loyalty (n.s.). Overall, the model for guests with loyalty membership was able to account for $37 \%$ of the variance in attitudinal loyalty, $F(9,490)=31.529, p>0.001$ and the model for guests without loyalty membership was able to account for $39 \%$ of the variance in attitudinal loyalty, $F(9,397)=31.774, p>0.001$. The behavioral models were much lower in their predictive power, but a positive relationship between attitudinal loyalty and behavioral loyalty was supported by the member sample and not supported by the non-member sample.

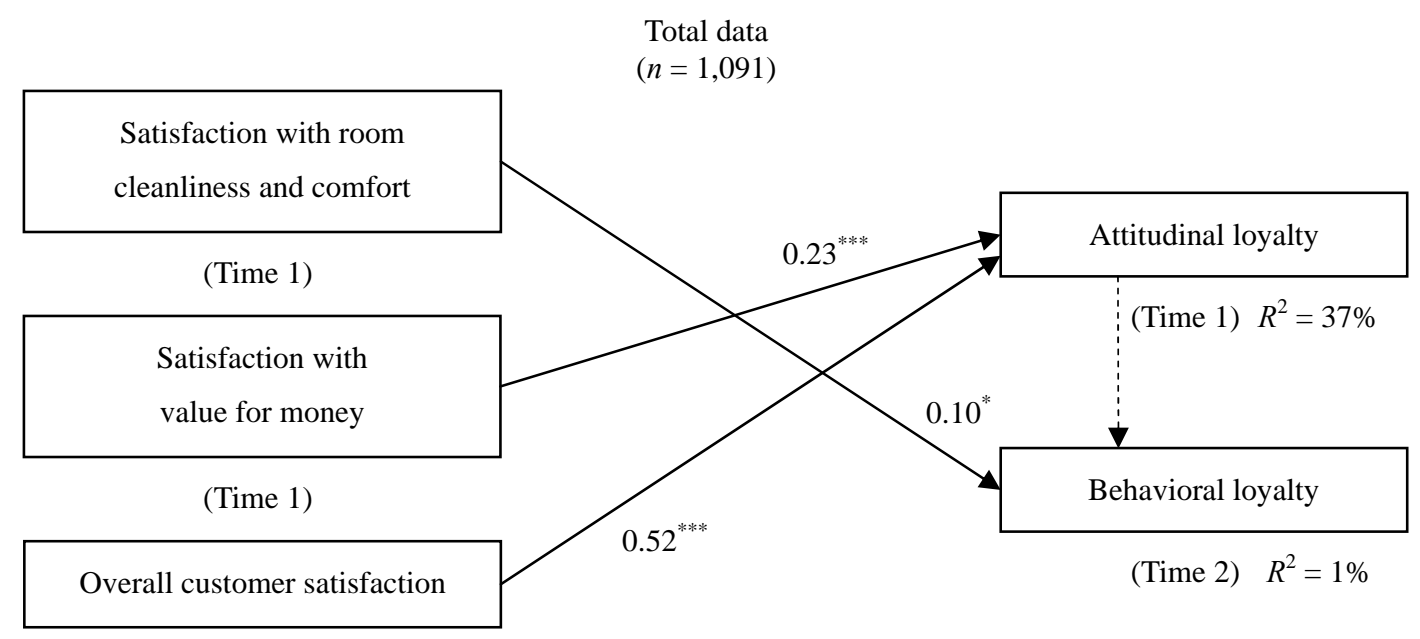

(Time 1)

Figure 1. Results of satisfaction-loyalty relationships. Note. ${ }^{* * *}: p<0.001 ;{ }^{*}: p<0.05$.

Table 5

Multiple Regression Analysis of Customer Satisfaction, Attitudinal Loyalty, and Behavioral Loyalty Between Loyalty Program Members and Non-members

\begin{tabular}{|c|c|c|c|c|c|c|c|c|}
\hline \multirow{3}{*}{$\begin{array}{l}\text { Satisfaction variables } \\
\text { and attitudinal loyalty }\end{array}$} & \multicolumn{4}{|c|}{ Guests with loyalty membership } & \multicolumn{4}{|c|}{ Guests without loyalty membership } \\
\hline & \multicolumn{2}{|c|}{ Attitudinal loyalty } & \multicolumn{2}{|c|}{ Behavioral loyalty } & \multicolumn{2}{|c|}{ Attitudinal loyalty } & \multicolumn{2}{|c|}{ Behavioral loyalty } \\
\hline & $\beta$ & $p$-value & $\beta$ & $p$-value & $\beta$ & $p$-value & $\beta$ & $p$-value \\
\hline Hotel location & -0.01 & Non-sig. & -0.05 & Non-sig. & 0.14 & $<0.05$ & 0.09 & Non-sig. \\
\hline $\begin{array}{l}\text { Room cleanliness and } \\
\text { comfort }\end{array}$ & 0.05 & Non-sig. & 0.02 & Non-sig. & 0.10 & Non-sig. & 0.17 & $<0.05$ \\
\hline Value for money & 0.24 & $<0.001$ & 0.14 & $<0.05$ & 0.19 & $<0.001$ & -0.11 & Non-sig. \\
\hline $\begin{array}{l}\text { Overall customer } \\
\text { satisfaction }\end{array}$ & 0.47 & $<0.001$ & -0.01 & Non-sig. & 0.57 & $<0.001$ & 0.03 & Non-sig. \\
\hline Attitudinal loyalty & -- & -- & 0.09 & $<0.05$ & -- & -- & -0.04 & Non-sig. \\
\hline$R^{2}$ & & $37 \%$ & & $1 \%$ & & $39 \%$ & & $3 \%$ \\
\hline
\end{tabular}

\section{Conclusions and Implications}

As one of the few empirical studies which measured both attitudinal loyalty and behavioral loyalty, the aim of this research was to examine the relationships among customer satisfaction, attitudinal loyalty, and behavioral loyalty. The discussion presents the theoretical and practical contributions of this study to the hospitality literature and for destination marketers and hospitality managers. 
Firstly, while overall customer satisfaction was significantly related to attitudinal loyalty, it was found to be unrelated to behavioral loyalty in this study. Although some previous studies (e.g., Bolton \& Lemon, 1999; Gilly \& Gelb, 1982; Solnick \& Hemenway, 1992) found that customers' repeated patronage behaviors depended on their prior satisfaction levels, customer satisfaction may incompletely explain behavioral loyalty, despite the fact that customer satisfaction is a necessary component for explaining behavioral loyalty (Gitelson \& Crompton, 1984). Previous literature provides some insight about the reasons why satisfied customers might switch their repeated patronage behaviors. For example, Gunn (1997) and Oppermann (1999) suggested that the impact of satisfaction on actual behavioral loyalty can be lower for the hospitality and tourism industry compared to other industries because satisfied customers might switch the destination even though they are happy with the service provided because of novelty seeking, convenience, competitive actions, or prices (Keaveney, 1995; Oliver, 1999; Reichheld, 1996; Stewart, 1997).

From the findings of this study, "satisfaction with value for money" was a significant predictor of behavioral loyalty for the membership group and "satisfaction with room cleanliness and comfort" was found to be a significant predictor of behavioral loyalty for all guests and for the segmented non-membership group. However, due to problems of low $R^{2}$ values and insignificant results of $F$-tests, the results need to be interpreted cautiously in drawing conclusions although significant coefficients still show that the model is valuable for showing about how changes in the predictor values are associated with changes in the response value (Frost, 2013).

Secondly, the relationship between attitudinal loyalty and behavioral loyalty was significant for only guests with loyalty membership. The low $R^{2}$ value suggests a weak relationship between attitudinal loyalty and actual future repeat behavior. These findings suggest that those who did not intend to return did; and those who planned to return didn't. Furthermore, customers may have a tendency to switch service providers despite high customer satisfaction ratings and attitudinal loyalty. Kraus (1995) argued that attitudinal loyalty predicts behavior, but it will not accurately predict a change in behavior. According to Back and Parks (2003) and Peter and Olson (1993), customers may switch to other options due to a decrease in positive attitudes about their current brand. Some studies suggest that the provider plays a very important role in the relationship between attitudinal and behavioral loyalty (Blackston, 1993; Fournier, 1998; Riley, Niininen, Szivas, \& Willis, 2001). Customers may want to go some new places for novelty and different experiences, although they remain loyal to the destination (Hsieh, O’Leary, \& Morrison, 1994; McDowall, 2010; Oppermann, 1999). Destination marketers need ways to target specific business customers who desire variety, but can be motivated to become destination loyal.

Thirdly, the findings of the study indicate that "satisfaction with value for money" and "overall satisfaction with a hotel stay" were found to be significant predictors of attitudinal loyalty. These findings concur with many previous empirical studies confirming the belief that customer satisfaction is an important antecedent to attitudinal loyalty (Back \& Parks, 2003; Bramwell, 1998; Fornell et al., 1996; Getty \& Thompson, 1995; Kozak, 2001; Kozak \& Rimmington, 2000; Yi \& La, 2004; Yoon \& Uysal, 2005). Further, this study showed that there were significant differences in the means of "satisfaction with value for money" and "overall satisfaction with a hotel stay" between loyalty program members and non-members and "satisfaction with value for money" is positively related to both attitudinal loyalty and behavioral loyalty with loyalty program members (O’Brien \& Jones, 1995; Poon \& Low, 2005; Shifflet \& Bhatia, 1997; Yi \& Jeon, 2003). From a chi-square test, it is showed that there were much more "very satisfied guests" in regard to "value for money" and "overall satisfaction” in the loyalty program members' group compared to the non-members' group. 
As discussed in the previous studies, customer perceived value is a powerful predictor of loyalty because customers choose a service provider, which offers the maximum value for money spent (Back \& Lee, 2009; Neal, 1999). Most hotels offer a loyalty program to foster customer loyalty as it is perceived as valuable and beneficial relative to the costs the members pay for membership (Dowling \& Uncles, 1997; Sellers, 1991). However, most programs look alike with similar benefits, which are easy to be copied by competitors and customers hold multiple loyalty membership cards within a similar industry (Mattila, 2006). Therefore, loyalty programs should be carefully planned, evaluated, and constantly developed based on a long-term relationship with customers that can elevate customer loyalty (Blackwell, Miniard, \& Engel, 2005; Choi \& Chu, 2001; Mattila, 2006; O’Brien \& Jones, 1995). To ensure that loyalty programs are attractive to customers and differentiated from the competing firms, loyalty programs can add more personal and subjective-oriented benefits such as feeling been entertained, honored, and delighted by "wowing” customers, which can produce emotional and interpersonal bonds between customers and a company, product, or service and the bonds can provide an important psychological value to the customers (Berman, 2006; Kim et al., 2013; Mattila, 2006). These emotional benefits can be perceived as more valuable to the customers than monetary rewards or extra discounts and ultimately, contribute to the formation of customer loyalty (Berman, 2006; Chiu, Hsieh, Li, \& Lee, 2005).

The findings of this study can help managers, operators, and owners better understand the relationships among satisfaction, attitudinal loyalty, and behavioral loyalty. Managers rely more upon customer's actual repeat behavior, rather than attitudinal loyalty, when estimating customer life-time value and developing cost-related strategies for a more realistic status of business performance (O’Malley, 1998; Oppermann, 1998; Shoemaker \& Bowen, 2003). However, focusing on only the behavioral aspects of loyalty may overestimate customer loyalty and fail to explain causes of loyal behavior such as attitudinal and psychological commitment to a product or service provider (Back, 2005; Day, 1969; Schall, 2003). Therefore, a clearer understanding of loyalty will allow them to develop more accurate tools to identify the gap between attitudinal loyalty and behavioral loyalty (O’Malley, 1998; Oppermann, 1998; Russell-Bennett et al., 2007).

It is likewise important for marketers and managers to obtain real-time continuous research with customers using a path relationship between customer satisfaction and loyalty. For example, managers may query a reservation system to find whether satisfied customers return on their own, or whether the hotel should use promotional incentives to encourage them to return. Additionally, managers need to consider whether a dissatisfied customer is likely to return. The dissatisfaction could result from a situation not under the control of the hotel. For example, the weather may be rainy and cold during a summer vacation week, or major road construction could significantly increase drive time to the hotel. There could be other ways that customer satisfaction leads to post-consumption behaviors including attitudinal and behavioral loyalty.

\section{Limitations and Future Research}

This study provides useful insights into loyalty research in the hospitality field using a rare combination of survey data and actual purchase transactions. Behavioral loyalty was measured from a single item that may not fully represent future behaviors (Bergkvist \& Rossiter, 2007; Laurent \& Kapferer, 1985). There could be possible omission of other predictors, which is important to behavioral loyalty in the context of hospitality industry. Researchers recommend the use of multiple items to improve quality measures, which strength the reliability of research findings. Future studies may add other behavioral measures, such as proportion of brand purchase (Li \& Petrick, 2008a; 2010; Yi \& La, 2004), and to attempt the addition of follow-up longitudinal studies over longer time periods. 
Another limitation of this study could be the low $R^{2}$ values in explaining variance of behavioral loyalty. Although $R^{2}$ value cannot determine whether the independent variables are a cause of the changes in the dependent variable (Frost, 2013), it provides a measure of how well observed outcomes are replicated by the model, as the proportion of total variation of outcomes explained by the model (Steel \& Torrie, 1960). The low $R^{2}$ values in explaining variance of behavioral loyalty mean that there could be possible exclusion of important predictors to behavioral loyalty. Therefore, future studies need to model more predictors in order to gain explanatory power.

Lastly, a possible limitation of this study is the fact that we collected the data from a single hotel, which is independently owned and operated without any brand affiliated. The loyalty program of brand-affiliated hotels usually provides additional benefits that can be earned and redeemed at any hotels under the same brand names (O’Neill \& Carlbäck, 2011). Future studies should include brand-affiliated hotels, where loyalty programs operate differently from those of independent hotels and should comparatively analyze the loyalty impact between independent and brand-affiliated hotels. Further, more empirical studies of the model in different populations of customers are also recommended, along with different types of accommodations and different service industries, as an effort to provide external validity.

\section{References}

Abubakar, B., \& Mavondo, F. (2014). Tourism destinations: Antecedents to customer satisfaction and positive word-of-mouth. Journal of Hospitality Marketing \& Management, 23(8), 833-864.

Ajzen, I., \& Fishbein, M. (1980). Understanding attitudes and predicting social behavior. Englewood Cliffs, NJ: Prentice Hall.

Back, K. J. (2005). The effects of image congruence on customers' brand loyalty in the upper middle-class hotel industry. Journal of Hospitality \& Tourism Research, 29(4), 448-467.

Back, K. J., \& Lee, J. S. (2009). Country club members' perceptions of value, image congruence, and switching costs: An exploratory study of country club members' loyalty. Journal of Hospitality \& Tourism Research, 33(4), 528-546.

Back, K. J., \& Parks, S. C. (2003). A brand loyalty model involving cognitive, affective, and conative brand loyalty and customer satisfaction. Journal of Hospitality \& Tourism Research, 27(4), 419-435.

Bagozzi, R. P., Baumgartner, J., \& Yi, Y. (1989). An investigation into the role of intentions as mediators of the attitude-behavior relationship. Journal of Economic Psychology, 10(1), 35-62.

Baldinger, A. L., \& Rubinson, J. (1996). Brand loyalty: The link between attitude and behavior. Journal of Advertising Research, 36, 22-36.

Bandyopadhyay, S., \& Martell, M. (2007). Does attitudinal loyalty influence behavioral loyalty? A theoretical and empirical study. Journal of Retailing and Consumer Services, 14(1), 35-44.

Bentler, P. M., \& Speckart, G. (1981). Attitudes “cause” behaviors: A structural equation analysis. Journal of Personality and Social Psychology, 40(2), 226-238.

Bergkvist, L., \& Rossiter, J. R. (2007). The predictive validity of multiple-item versus single-item measures of the same constructs. Journal of Marketing Research, 44(2), 175-184.

Berman, B. (2006). Developing an effective customer loyalty program. California Management Review, 49(1), 123-148.

Bigné, E., Küster, I., \& Torán, F. (2003). Market orientation and industrial salesforce: Diverse measure instruments. Journal of Business \& Industrial Marketing, 18(1), 59-81.

Blackston, M. (1993). Beyond brand personality: Building brand relationships. In D. A. Aaker, \& A. L. Biel (Eds.), Brand equity \& advertising: Advertising's role in building strong brands (pp. 113-124). Psychology Press.

Blackwell, R. D., Miniard, P. W., \& Engel, J. F. (2005). Consumer behaviour. Cincinnati, OH: South Western College Publishing.

Bodet, G. (2008). Customer satisfaction and loyalty in service: Two concepts, four constructs, several relationships. Journal of Retailing and Consumer Services, 15(3), 156-162.

Bolton, R. N., \& Lemon, K. N. (1999). A dynamic model of customers' usage of services: Usage as an antecedent and consequence of satisfaction. Journal of Marketing Research, 36, 171-186. 
Bolton, R. N., Kannan, P. K., \& Bramlett, M. D. (2000). Implications of loyalty program membership and service experiences for customer retention and value. Journal of the Academy of Marketing Science, 28(1), 95-108.

Bramwell, B. (1998). User satisfaction and product development in urban tourism. Tourism Management, 19(1), 35-47.

Bridson, K., Evans, J., \& Hickman, M. (2008). Assessing the relationship between loyalty program attributes, store satisfaction and store loyalty. Journal of Retailing and Consumer Services, 15(5), 364-374.

Budeanu, A. (2007). Sustainable tourist behaviour - A discussion of opportunities for change. International Journal of Consumer Studies, 31(5), 499-508.

Carlsson, F., \& Löfgren, Å. (2006). Airline choice, switching costs and frequent flyer programmes. Applied Economics, 38(13), 1469-1475.

Chandon, P., Morwitz, V. G., \& Reinartz, W. J. (2005). Do intentions really predict behavior? Self-generated validity effects in survey research. Journal of Marketing, 69(2), 1-14.

Chiu, H. C., Hsieh, Y. C., Li, Y. C., \& Lee, M. (2005). Relationship marketing and consumer switching behavior. Journal of Business Research, 58(12), 1681-1689.

Choi, T. Y., \& Chu, R. (2001). Determinants of hotel guests' satisfaction and repeat patronage in the Hong Kong hotel industry. International Journal of Hospitality Management, 20(3), 277-297.

Day, G. S. (1969). A two-dimensional concept of brand loyalty. Journal of Marketing Research, 9, 29-36.

Dick, A. S., \& Basu, K. (1994). Customer loyalty: Toward an integrated conceptual framework. Journal of the Academy of Marketing Science, 22(2), 99-113.

Dowling, G. R., \& Uncles, M. (1997). Do customer loyalty programs really work? Sloan Management Review, 38(4), 71-82.

Dubé, L., \& Renaghan, L. M. (2000). Creating visible customer value: How customers view best-practice champions. The Cornell Hotel and Restaurant Administration Quarterly, 41(1), 62-72.

Evanschitzky, H., Iyer, G. R., Plassmann, H., Niessing, J., \& Meffert, H. (2006). The relative strength of affective commitment in securing loyalty in service relationships. Journal of Business Research, 59(12), 1207-1213.

Finn, A. (2005). Reassessing the foundations of customer delight. Journal of Service Research, 8(2), 103-116.

Fishbein, M., \& Ajzen, I. (1975). Belief, attitude, intention, and behavior: An introduction to theory and research. Reading, MA: Addison-Wesley.

Fornell, C., Johnson, M. D., Anderson, E. W., Cha, J., \& Bryant, B. E. (1996). The American customer satisfaction index: Nature, purpose, and findings. The Journal of Marketing, 60, 7-18.

Fournier, S. (1998). Consumers and their brands: Developing relationship theory in consumer research. Journal of Consumer Research, 24(4), 343-373.

Frost, J. (2013). Regression analysis: How do I interpret R-squared and assess the goodness-of-fit. The Minitab Blog, 30.

Getty, J. M., \& Thompson, K. N. (1995). The relationship between quality, satisfaction, and recommending behavior in lodging decisions. Journal of Hospitality \& Leisure Marketing, 2(3), 3-22.

Gilly, M. C., \& Gelb, B. D. (1982). Post-purchase consumer processes and the complaining consumer. Journal of Consumer Research, 9(3), 323-328.

Gitelson, R. J., \& Crompton, J. L. (1984). Insights into the repeat vacation phenomenon. Annals of Tourism Research, 11(2), 199-217.

Gunn, C. A. (1997). Vacationscape: Developing tourist areas. Washington, DC: Taylor \& Francis.

Hammond, K., East, R., \& Ehrenberg, A. (1996). Buying more and buying longer: Concepts and applications of consumer loyalty. London: London Business School.

Han, H., \& Back, K. J. (2007). Investigating the effects of consumption emotions on customer satisfaction and repeat visit intentions in the lodging industry. Journal of Hospitality \& Leisure Marketing, 15(3), 5-30.

Hsieh, S., O’Leary, J. T., \& Morrison, A. M. (1994). A comparison of package and non-package travelers from the United Kingdom. Journal of International Consumer Marketing, 6(3-4), 79-100.

Jacoby, J., \& Chestnut, R. (1978). Brand loyalty measurement and management. New York, NY: John Wiley \& Sons.

Jang, D., \& Mattila, A. S. (2005). An examination of restaurant loyalty programs: What kinds of rewards do customers prefer? International Journal of Contemporary Hospitality Management, 17(5), 402-408.

Keaveney, S. M. (1995). Customer switching behavior in service industries: An exploratory study. The Journal of Marketing, 59(2), 71-82.

Kim, M. G., Lee, C. H., \& Mattila, A. S. (2014). Determinants of customer complaint behavior in a restaurant context: The role of culture, price level, and customer loyalty. Journal of Hospitality Marketing \& Management, 23(8), 885-906. 
Kim, M. R., Vogt, C. A., \& Knutson, B. J. (2013). Relationships among customer satisfaction, delight, and loyalty in the hospitality industry. Journal of Hospitality \& Tourism Research. doi: 10.1177/1096348012471376

Knutson, B. J. (1988). Frequent travelers: Making them happy and bringing them back. The Cornell Hotel and Restaurant Administration Quarterly, 29(1), 82-87.

Kozak, M. (2001). Repeaters' behavior at two distinct destinations. Annals of Tourism Research, 28(3), 784-807.

Kozak, M., \& Rimmington, M. (2000). Tourist satisfaction with Mallorca, Spain, as an off-season holiday destination. Journal of Travel Research, 38(3), 260-269.

Kraus, S. J. (1995). Attitudes and the prediction of behavior: A meta-analysis of the empirical literature. Personality and Social Psychology Bulletin, 21(1), 58-75.

Kwortnik, R. J., Jr., \& Han, X. (2011). The influence of guest perceptions of service fairness on lodging loyalty in China. Cornell Hospitality Quarterly, 52(3), 321-332.

Laurent, G., \& Kapferer, J. N. (1985). Measuring consumer involvement profiles. Journal of Marketing Research, 22(1), 41-53.

Li, X., \& Petrick, J. F. (2008a). Reexamining the dimensionality of brand loyalty: A case of the cruise industry. Journal of Travel \& Tourism Marketing, 25(1), 68-85.

Li, X., \& Petrick, J. F. (2008b). Examining the antecedents of brand loyalty from an investment model perspective. Journal of Travel Research, 47(1), 25-34.

Li, X., \& Petrick, J. F. (2010). Towards an integrative model of loyalty formation: The role of quality and value. Leisure Sciences, 32(3), 201-221.

Mattila, A. S. (2006). How affective commitment boosts guest loyalty (and promotes frequent-guest programs). Cornell Hospitality Quarterly, 47(2), 174-181.

McDowall, S. (2010). International tourist satisfaction and destination loyalty: Bangkok, Thailand. Asia Pacific Journal of Tourism Research, 15(1), 21-42.

McKercher, B., \& Tse, S. M. (2012). Is intention to return a valid proxy for actual repeat visitation? Journal of Travel Research, 51(6), 671-686.

McMullan, R., \& Gilmore, A. (2003). The conceptual development of customer loyalty measurement: A proposed scale. Journal of Targeting, Measurement and Analysis for Marketing, 11, 230-243.

Meyer-Waarden, L. (2008). The influence of loyalty programme membership on customer purchase behaviour. European Journal of Marketing, 42(1/2), 87-114.

Mittal, B., \& Lassar, W. M. (1998). Why do customers switch? The dynamics of satisfaction versus loyalty. Journal of Services Marketing, 12(3), 177-194.

Morais, D. B., Dorsch, M. J., \& Backman, S. J. (2004). Can tourism providers buy their customers' loyalty? Examining the influence of customer-provider investments on loyalty. Journal of Travel Research, 42(3), 235-243.

Neal, W. D. (1999). Satisfaction is nice, but value drives loyalty. Marketing Research, 11(1), 20-23.

O’Brien, L., \& Jones, C. (1995). Do rewards really create loyalty? Long Range Planning, 28(4), 130.

O’Malley, L. (1998). Can loyalty schemes really build loyalty? Marketing Intelligence \& Planning, 16(1), 47-55.

O’Neill, J. W., \& Carlbäck, M. (2011). Do brands matter? A comparison of branded and independent hotels’ performance during a full economic cycle. International Journal of Hospitality Management, 30(3), 515-521.

Oliver, R. L. (1980). A cognitive model of the antecedents and consequences of satisfaction decisions. Journal of Marketing Research, 17(4), 460-469.

Oliver, R. L. (1993). Cognitive, affective, and attribute bases of the satisfaction response. Journal of Consumer Research, 20(3), 418-430.

Oliver, R. L. (1999). Whence consumer loyalty? Journal of Marketing, 63, 33-44.

Oppermann, M. (1998). Destination threshold potential and the law of repeat visitation. Journal of Travel Research, 37(2), 131-137.

Oppermann, M. (1999). Predicting destination choice - A discussion of destination loyalty. Journal of Vacation Marketing, 5(1), 51-65.

Oppermann, M. (2000). Tourism destination loyalty. Journal of Travel Research, 39(1), 78-84.

Peter, J. P., \& Olson, J. C. (1993). Consumer behavior and marketing strategy (3rd ed.). Chicago, IL: Irwin.

Petrick, J. F. (2005). Reoperationalising the loyalty framework. Tourism and Hospitality Research, 5(3), 199-212.

Poon, W. C., \& Low, K. L. T. (2005). Are travellers satisfied with Malaysian hotels? International Journal of Contemporary Hospitality Management, 17(3), 217-227. 
Pritchard, M. P., Howard, D. R., \& Havitz, M. E. (1992). Loyalty measurement: A critical examination and theoretical extension. Leisure Sciences, 14(2), 155-164.

Reichheld, F. F. (1996). The loyalty effect. Boston, MA: Harvard Business School Press.

Riley, M., Niininen, O., Szivas, E. E., \& Willis, T. (2001). The case for process approaches in loyalty research in tourism. International Journal of Tourism Research, 3(1), 23-32.

Russell-Bennett, R., McColl-Kennedy, J. R., \& Coote, L. V. (2007). Involvement, satisfaction, and brand loyalty in a small business services setting. Journal of Business Research, 60(12), 1253-1260.

Schall, M. (2003). Best practices in the assessment of hotel-guest attitudes. The Cornell Hotel and Restaurant Administration Quarterly, 44(2), 51-65.

Sellers, P. (1991, July 29). Winning over the new consumer. Fortune, pp. 113-124.

Sharp, B., \& Sharp, A. (1997). Loyalty programs and their impact on repeat-purchase loyalty patterns. International Journal of Research in Marketing, 14(5), 473-486.

Shifflet, D. K., \& Bhatia, P. (1997). Perception of value often leads to loyalty. Hotel \& Motel Management, $211(16), 22$.

Shoemaker, S., \& Bowen, J. T. (2003). Commentary on "loyalty: A strategic commitment”. Cornell Hotel and Restaurant Administration Quarterly, 44(5-6), 47-52.

Solnick, S. J., \& Hemenway, D. (1992). Complaints and disenrollment at a health maintenance organization. Journal of Consumer Affairs, 26(1), 90-103.

Spreng, R. A., MacKenzie, S. B., \& Olshavsky, R. W. (1996). A reexamination of the determinants of consumer satisfaction. Journal of Marketing, 60(3), 15-32.

Steel, R. G. D., \& Torrie, J. H. (1960). Principles and procedures of statistics with special reference to the biological sciences. New York, NY: McGraw-Hill.

Stewart, T. A. (1997). A satisfied customer isn't enough. Fortune, 136, 112-113.

Thaler, R. (1985). Mental accounting and consumer choice. Marketing Science, 4(3), 199-214.

Tsai, H., Yeung, S., \& Yim, P. H. L. (2011). Hotel selection criteria used by Mainland Chinese and foreign individual travelers to Hong Kong. International Journal of Hospitality \& Tourism Administration, 12(3), 252-267.

Wright, C., \& Sparks, L. (1999). Loyalty saturation in retailing: Exploring the end of retail loyalty cards? International Journal of Retail \& Distribution Management, 27(10), 429-440.

Yi, Y., \& Jeon, H. (2003). Effects of loyalty programs on value perception, program loyalty, and brand loyalty. Journal of the Academy of Marketing Science, 31(3), 229-240.

Yi, Y., \& La, S. (2004). What influences the relationship between customer satisfaction and repurchase intention? Investigating the effects of adjusted expectations and customer loyalty. Psychology \& Marketing, 21(5), 351-373.

Yoon, Y., \& Uysal, M. (2005). An examination of the effects of motivation and satisfaction on destination loyalty: A structural model. Tourism Management, 26(1), 45-56. 